\title{
Controlled Cyclophotocoagulation
}

\author{
Paul-Rolf Preußner \\ University Eye Hospital, Langenbeckstr \\ Germany
}

\section{Introduction}

Glaucoma treatments which partially destroyed the ciliary body started already in the thirthies of the 20th century. Heat and cold were used for this purpose, delivered from different devices such as hot needles, cryo applicators, ultrasound generators or radiation devices. All these methods were successful in lowering introcular pressure, but many eyes were lost and ended in a phthisis. The reasons of such disastrous outcomes is not fully investigated in all details, but it is mostly assumed that the production of aqueous humor has been reduced too much. In summary, the methods were called "cyclodestructive", a wording primarily related to the destruction of tissue in the ciliary body, but also making graphical the high destructive potential to the eye.

With the invention of lasers, many CW-lasers were utilized for tissue coagulation of the ciliary body, and the new word "cyclophotocoagulation" was created, also to distinguish photo- from cryocoagulation (1-13).

For a long time, current opinion was to restrict cyclophotocoagulation to intractable cases due to severe complications which had been observed by several authors (e.g. (14-21)). Meanwhile, however, transscleral cyclophotocoagulation is proposed also as primary therapy $(22 ; 23)$.

An improvement of the coagulation was achieved by the introduction of contact methods (24), however, efforts undertaken in the past to optimize therapy parameters (25-29) including aspects of radiation transport $(30 ; 31)$ could not solve the principal problem that the laser burns cannot be observed directly.

Without information about coagulation success, dosage cannot be adjusted to the individual situation which shows a strong inter- and intraindividual variation of optical properties of the corresponding tissue (32). For the reasons mentioned, we had developed a real-time control system $(33 ; 34)$ to solve this problem.

\section{Controlling device}

During coagulation of the tissue, chemical and physical effects are induced which change the optical properties, i.e. the transmission, absorption and reflection in this material (35). For the ciliary body, this effect cannot be observed directly. However, the transmitted laser radiation produces diffuse stray light which is partly reflected from the fundus and can be observed from outside the eye by a sensor. The principle of the corresponding device is illustrated in fig. 1 . The light intensity monitored by the sensor during the laser exposure depends on many 


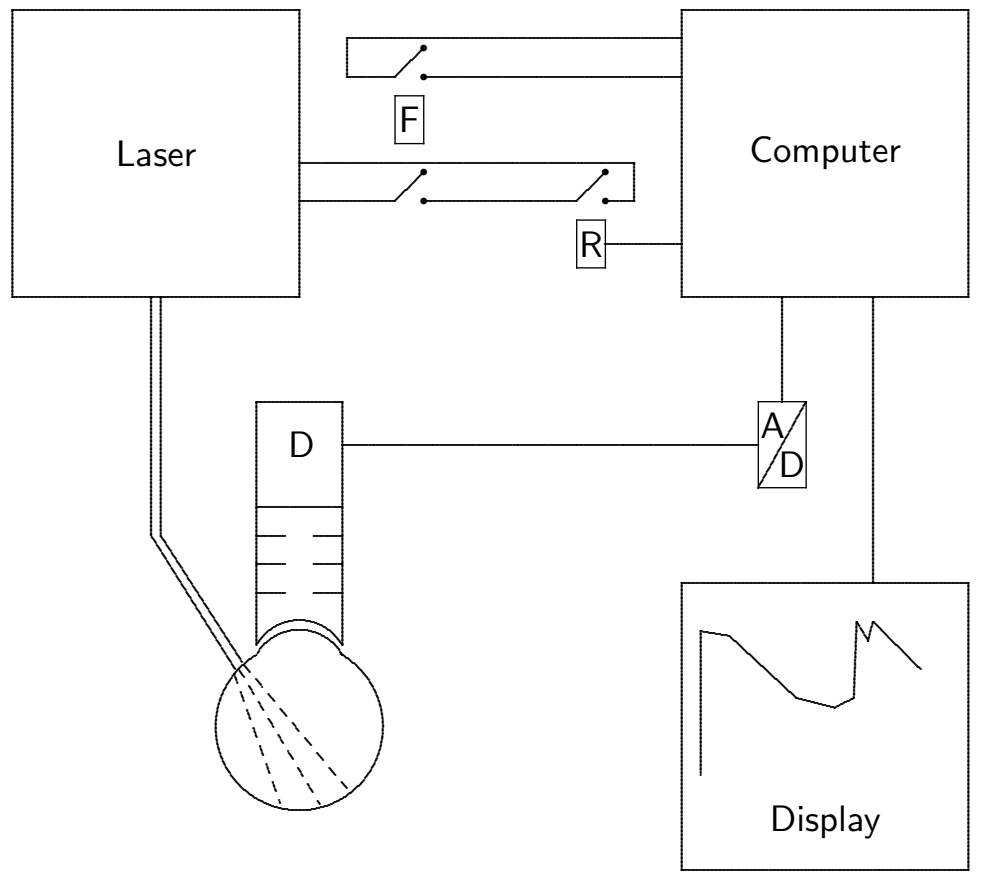

Fig. 1. Functional Diagram. The laser radiation passing through sclera and ciliary body is partly reflected from the fundus and recorded by a detector $\mathrm{D}$. The amplified electronical signal is digitized by an A/D-converter, recorded by a computer and displayed on a screen in real time. The whole process is initiated by pressing the foot-switch $\mathrm{F}$, which starts the computer and closes one of the switches for the laser device. The second one is closed by a semiconductor-relay $\mathrm{R}$, which is controlled by the computer. Exposure is stopped either if the operator (viewing the screen) releases his foot-switch $\mathrm{F}$ or if the computer opens the relay $\mathrm{R}$, when the recorded signal has fulfilled certain programmable criteria.

parameters such as fundus reflectivity, pupil width etc. and can therefore not be used directly as an absolute measure of the coagulation stage of the tissue. However, the coagulation process changes the light observed as function of time in any case. Therefore, this time dependence can be used to monitor the progress of coagulation. The electronic signal has to be normalized to its starting value, i.e., only relative values are used for further evaluation.

There are 2 ways the process can be controlled. First, the surgeon can interrupt the exposure if the displayed curve of changing transmission has a certain shape. This is possible, but difficult, because typical time scales are in the range of $0.1-0.5 \mathrm{~s}$, which is approximately the surgeon's own reaction time. As a second "operator", the computer can interrupt the exposure.

\section{Physical parameters}

\subsection{Laser power}

Laser power has to be adjusted in such a way that the target tissue is coagulated as selectively as possible, thereby saving all surrounding tissues. The physical parameters describing this 


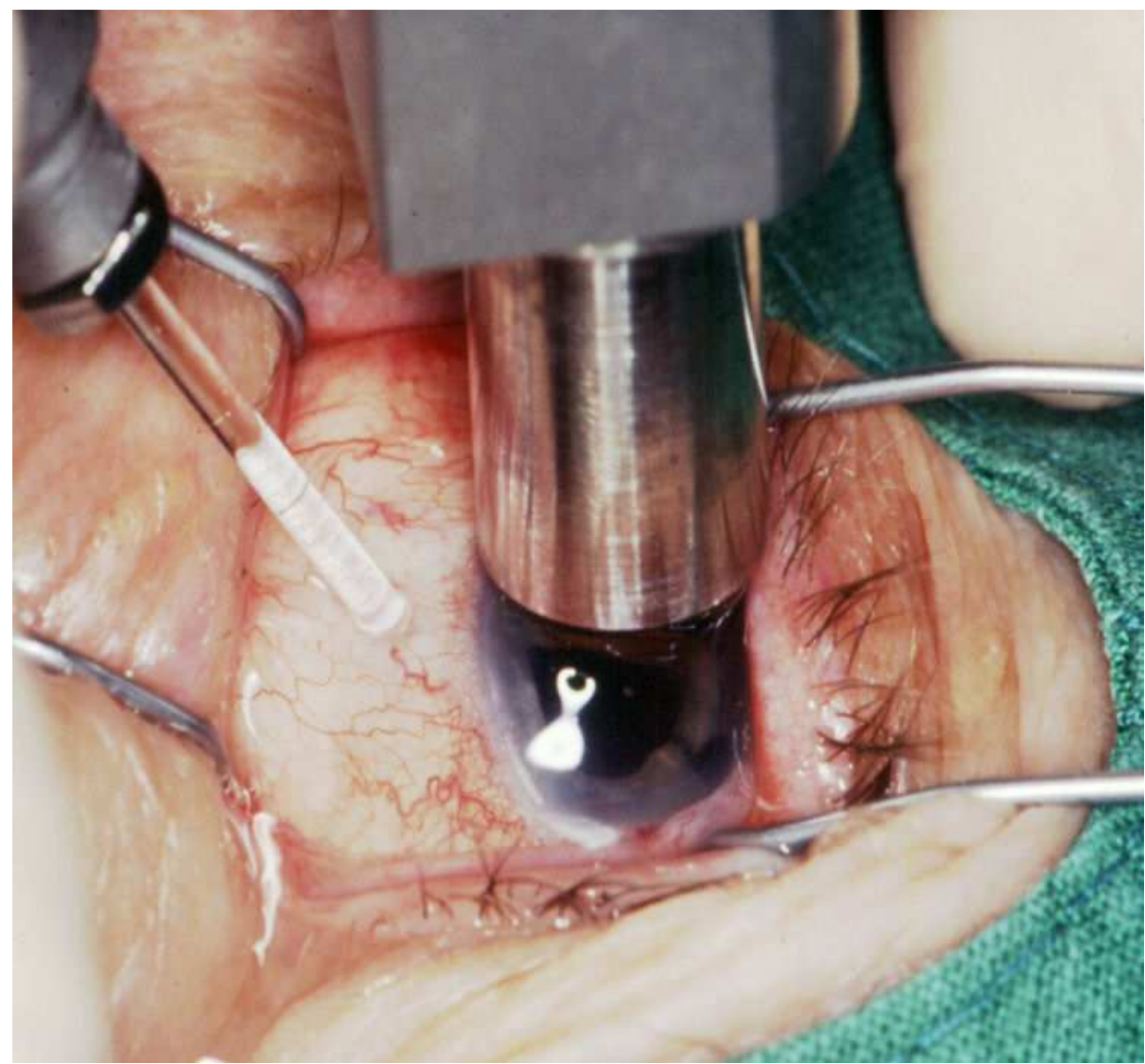

Fig. 2. Application to a Patient's Eye

in context are the temperature gradient and the heat conduction, which determine the thermal relaxation time. If laser power is too low, a long time is needed until coagulation starts. During this time, a high portion of heat is already dissipated into the surrounding tissue. This results in an unwanted large area of coagulated tissue, which can also be observed from the high value of the total energy, the product of power and time. A very high laser power, on the other hand, induces a steep temperature gradient with a higher risk of overheating parts of the target tissue before the rest is sufficiently coagulated. Such overheated tissue has a high probability of so-called "pop spots". A pop spot is a local overheating of the tissue in which the tissue membranes are disrupted by the steam pressure with an audible "pop" as in a pop corn.

As a compromise, we preferably use a laser power of $5 \mathrm{~W}$ for the $810 \mathrm{~nm}$ diode laser in Caucasian eyes and found the same value suitable for the 940nm laser in African eyes. Only in very rare cases of buphthalmos with very thin sclera this value has to be reduced to $3 \mathrm{~W}$. 


\subsection{Laser wavelength}

The laser wavelength for transscleral cyclophotocoagulation must be selected in such a way that the laser light is transmitted through the conjunctiva, the sclera and the ciliary muscle, and that it is absorbed by the pigment epithelium of the ciliary body. These requirements, however, can only be fulfilled approximatively, depending on the spectral characteristics of the eye.

Caucasian and African eyes strongly differ in the absorption and transmission of visible and infrared radiation. If the absorption is too high, the fraction of energy already absorbed in conjunctiva, sclera or ciliary muscle causes an unwanted overheating of these tissues. Absorption and transmission of ocular tissues show a strong wavelength dependence (36). The spectra shown is this paper are consistent with the fact that the flux density needed for the 1064nm Nd:YAG laser is approximately 2-fold higher than with the 810nm diode laser. They also show that the same behavior as with the 810nm laser in Caucasian eyes could be expected with a $940 \mathrm{~nm}$ laser in African eyes. In a few African eyes treated with the $810 \mathrm{~nm}$ laser in Mainz University Eye Hospital, the abovementioned real-time control did not work, i.e. many pop spots occured. Therefore, after tests with African cadaver eyes in Ghana (43), the 940nm laser was clinically established in Cameroun.

Applications of shorter wavelengths for transscleral cyclophotocoagulation in the visible red range have been reported only by Scandinavian authors for a population with very lightly pigmented eyes $(8 ; 37 ; 38)$, again consistent with the spectra in $(36)$.

\subsection{Location}

As location, we chose the transition region between pars plicata and pars plana of the ciliary body, i.e., $3-3.5 \mathrm{~mm}$ posterior to the limbus. We intend to coagulate at least a part of the secreting tissue, but care should be taken of the ciliary muscle including fixation of zonula fibers (which could be disintegrated), because the procedure should also be applicable to phakic, accommodating eyes. The effectiveness of even higher limbus distances has been proven by other authors (39). Fortunately, our real-time control shows optimal performance just in the chosen limbus distance.

Normally, $360^{\circ}$ are treated. The only exceptions are scleral lesions / thinned sclera, particularly the areas of previous trabeculectomies.

\subsection{Optic of the laser applicator}

The laser applicator (the tip directly pressed on the eye) should be designed in such a way that the optical power density at the conjunctiva is minimal and the power density in the target tissue (ciliary body) is maximal. Focussing therefore seems to be a reasonable procedure. Unfortunately, the outcome of focussing is rather poor. If a (spherical) lens is used, even for a material with a high refractive index a relatively long focal width results, because the refractive index of the sclera is similar to that of water, i.e., much larger than one. This problem could be solved in principle by a so-called "gradient index lens" (40), for which the focal width can be set to any position. But, our own measurements and calculations (31) also with such optical devices have shown that diffuse multiple scattering in scleral tissue largely neutralises the focussing effect. Fortunately, radiation transport can be optimised by an appropriate choice of the diameter of the optical tip. As shown in (31), this diameter should be larger than or at least equal to the thickness of the sclera. On the other hand, a smaller tip diameter theoretically causes a higher pressure on the sclera leading to an improved optical transmission $(41 ; 42)$. Thus, both effects have to be balanced against each other by an optimal 
tip diameter. Tests in Caucasian and African cadaver eyes showed that a tip diameter of $1.5 \mathrm{~mm}$ was optimal for Caucasian and of $1.95 \mathrm{~mm}$ for African eyes.

\subsection{Shape of transmission curves}

Typical curves resulting from coagulation in porcine eyes, Caucasian cadaver eyes and in the eyes of Caucasian patients are in detail reported in (33), see fig. 3 for an example. The curves of African eyes principally show the same shape, but with slightly different amplitudes from minimum to maximum which therefore needed different software settings.

The shape of these curves (see fig.3) corresponds to the temperature change in the target tissue: In the first, horizontal part (1), no irreversible chemical or physical effects occur, therefore the transmission in the tissue remains constant. The temperature may increase to about $45-50^{\circ} \mathrm{C}$. In the second, decreasing part (2), the transmission is reduced mainly by shrinkage of the tissue. The temperature further increases to about $60-70^{\circ} \mathrm{C}$. After that, only minor changes in the transmission occur (3), but the temperature increases to a value above $100^{\circ} \mathrm{C}$. Trapped, overheated steam then disrupts tissue membranes in the "pop spot". Since for the "wanted" effect of irreversible coagulation, a temperature of about $55-60^{\circ} \mathrm{C}$ is sufficient, the process should be interrupted at the end of phase two. This is normally less than $1 / 3$ of the time to pop spot, because at the beginning of the coagulation, the temperature raise is steeper than at the end due to heat dissipation to the neighbourhood. Fortunately, further heating above $60^{\circ} \mathrm{C}$ but well below $100^{\circ} \mathrm{C}$ is not critical, thus giving a relative safe "therapeutic window" before a pop spot occurs.

\section{Clinical applications}

\subsection{Indication}

Controlled cyclophotocoagulation is indicated in all open angle glaucomas in which eye drops do not effectively reduce the intraocular pressure. This includes cases of insufficient compliance in industrial countries as well as developing countries in which eye drops are not available or not effordable. In severe cases of hemorrhagical secondary glaucoma in blind eyes even repeated controlled cyclophotocoagulation may be insufficient and should be replaced by cryocoagulation.

\subsection{Preoperative preparation and anesthesia}

It is recommended to dilate the pupil preoperatively because it increases the signal-to-noise-ratio of the detector of the real time control, but when the pupil cannot be dilated, the procedure can be applied anyway.

Anesthesia can be a para- or retrobulbar injection, or a general anesthesia, or a combination of topical anesthesia by eye drops and general analgesia (e.g. Propofol combined with a short acting opioid). Topical anesthesia alone with eye drops is insufficient. In case of para- or retrobulbary injections, it should be kept in mind that the risk of these injections is higher than that of the controlled cyclophotocoagulation. Analgesia alone needs very high drug doses when the simulataneous topical anesthesia is omitted.

\subsection{Treatment}

Generally, 16 spots are applied over $360^{\circ}$. A larger number (24 spots) did not result in a significantly higher IOP reduction, but in a significantly higher and longer lasting 


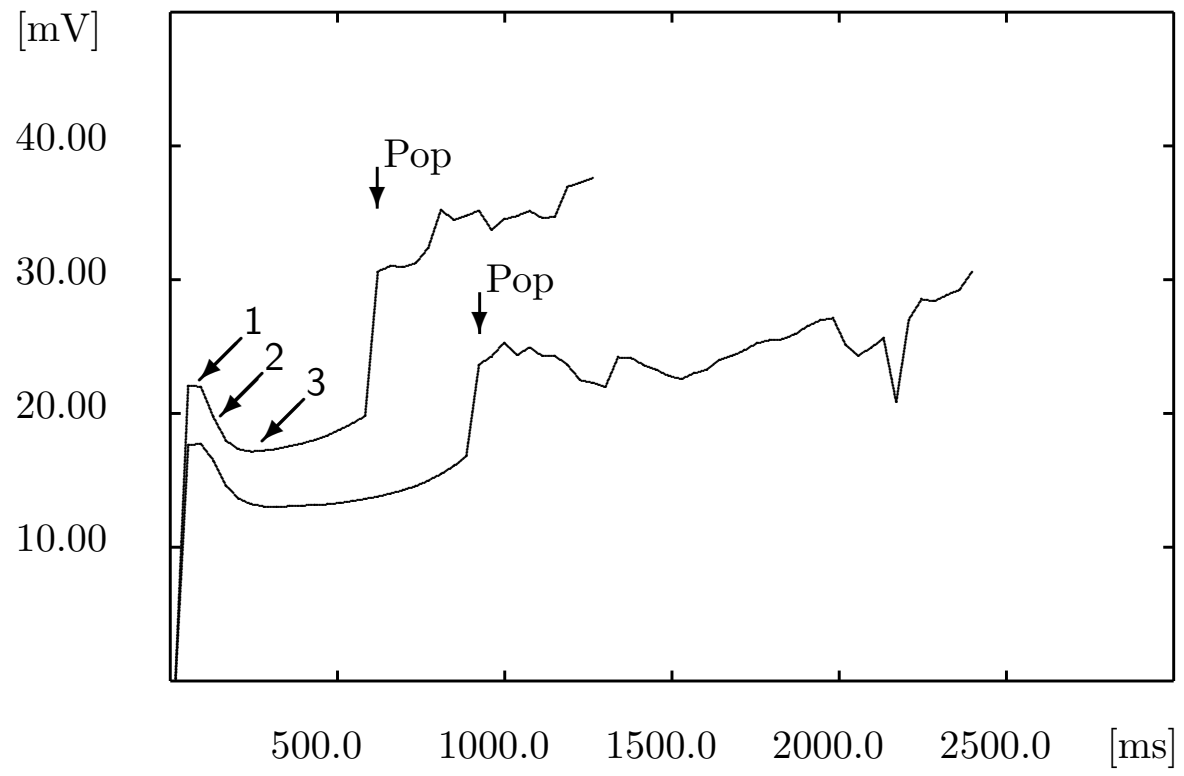

Fig. 3. Typical Transmission Curves. The recordings are from porcine eyes. The numbers $(1,2,3)$ and their meaning are explained in the text.

inflammation reaction (cells). An integrated instrument comprising laser source and computer and its application in Cameroun is shown in fig.4.

\subsection{Postoperative medication}

After surgery, local antibiotics are applied once in order to prevent infections based on minor (and prehaps overlooked) corneal or conjinctival lesions. Local steroids and Scopolamin or Homatropine are applied until there are no more signs of inflammation (cells) visible at the slitlamp.

\subsection{Complications}

Major complications such as intraocular bleedings, shallow anterior chamber, chorioideal detachment, ocular hypotension $<7 \mathrm{mmHg}$ or phthisis have not been observed during more than 2000 treatments of Caucasian patients with the 810nm laser in the university eye hospital of Mainz, Germany, nor in more than 1000 treatments of African patients with the 940nm laser in the eye clinic at Acha Bafoussam, Cameroun. Such complications also did not come to our knowledge from other hospitals using this method.

Some minor complications can happen from time to time:

Conjunctival hemorrhages can occur at the locations where the tip is placed on the conjunctiva, particularly in patients with systemic anticoagulation. Depending on the surgeons' experience and care also corneal erosions can be produced. Intraocular iritis (cells) 


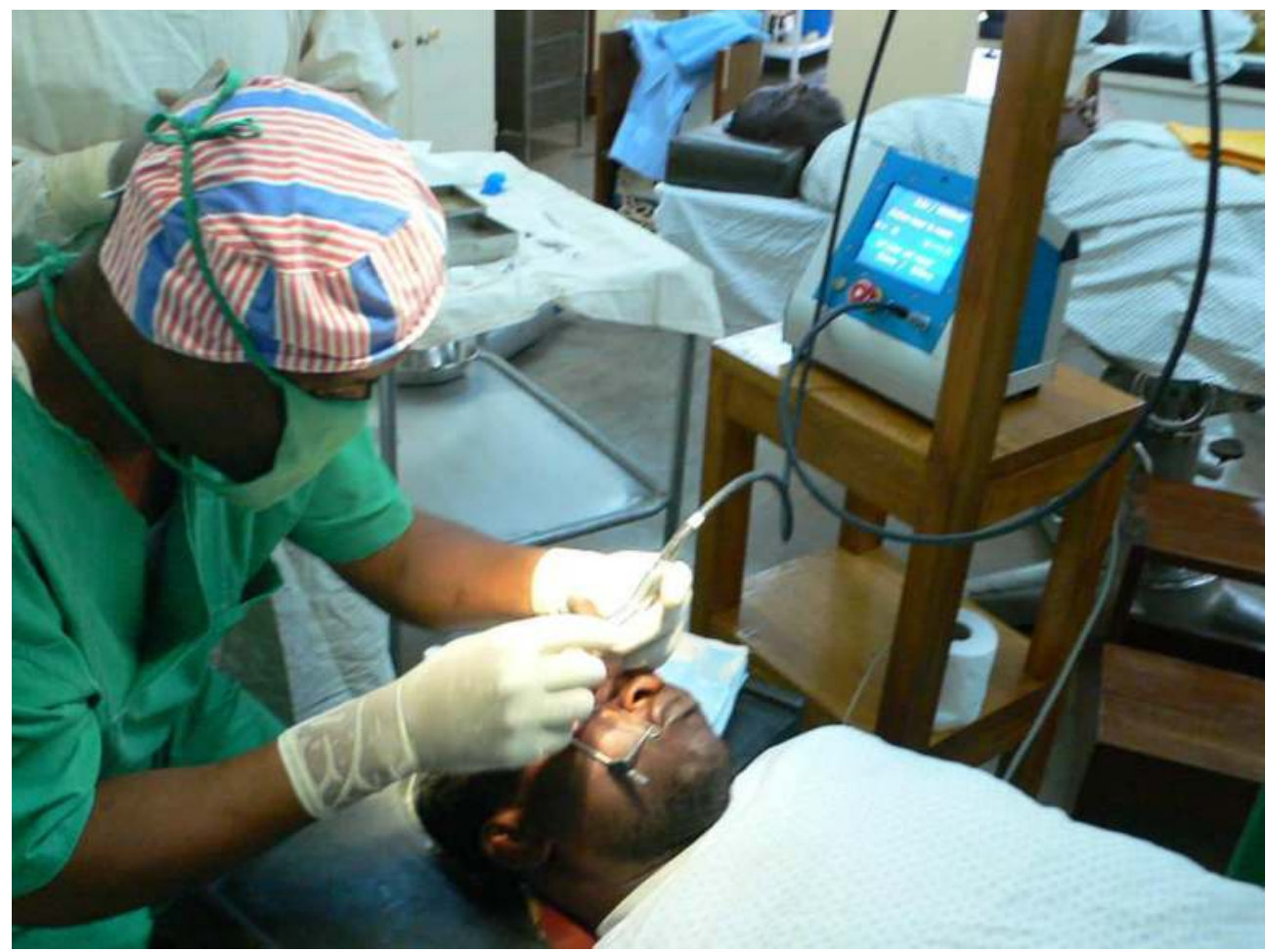

Fig. 4. Application in Camerounian Patients

mostly disappear after one or two days, and higher degrees of inflammation (fibrin exudation) is extremely rare ( $<1 \%$ of the treatments).

In our opinion, also pop spots should be looked at as complications. Even if the probability of pop spots is highly reduced by the real-time control of the coagulation, this probability is not zero. In Caucasian eyes one or more pop spots occur in $\approx 20 \%$ of the eyes, in African eyes in $\approx 30 \%$.

Even if visual acuity as a measure of unwanted side effects has been recorded pre- and postoperatively, the data have not been evaluated systematically. They are often incomplete and biased by the often unknown refraction and by additional reasons (e.g. cataract) that worsens visual acuity. Nevertheless, a significant decrease following the treatment did not occur. It did, however, in Mainz University eye hospital in one case that was treated with 24 spots in the starting phase. The reason was a macula edema. With the generally recommended protocol of 16 spots no further macula edema was observed.

\subsection{Influence on Intraocular Pressure (IOP)}

\subsubsection{Caucasian eyes}

Despite the high treatment numbers in the University Eye Hospital Mainz, these patients could not be followed up systematically because of the deduction rules of the health insurance. Patients are referred from other doctors to the University Hospital, but seen again only in case 
of complications or isufficient treatment. Fig.5 shows the IOP of another German hospital which could do a systematic follow-up without selection bias.

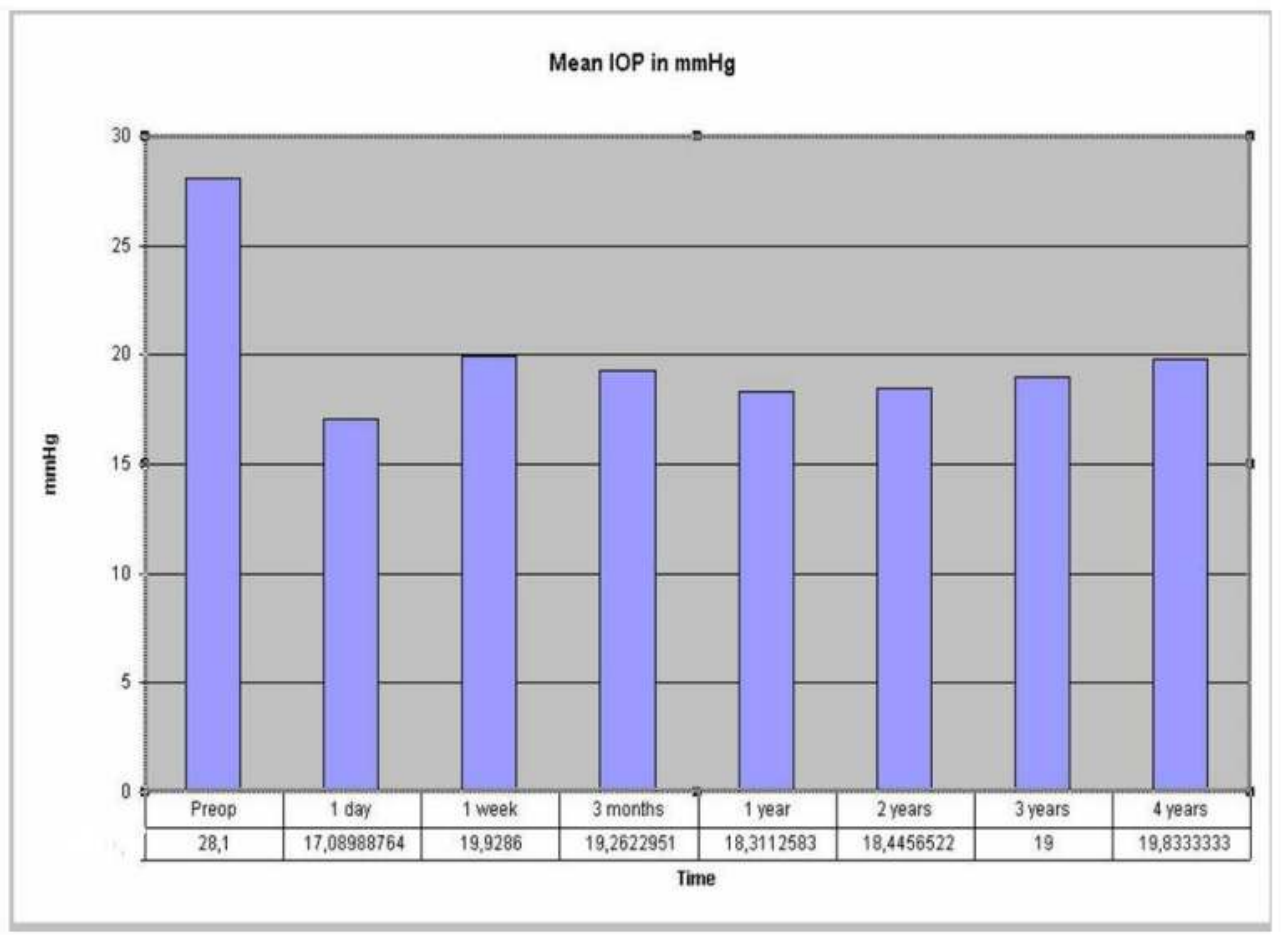

Fig. 5. Intraocular Pressure in European Eyes. The IOP of 40 eyes in which controlled cyclophotocoagulation was the 1st and only glaucoma surgery is shown as function of the follow-up time of 4 years. The numbers on the bottom of each column show the averages. (Picture by courtesy of Dr. Gerl, Dr. Schmickler, Augenklinik Ahaus, Germany)

\subsubsection{African eyes}

272 eyes of 188 patients with primary open angle glaucoma were treated in the eye hospital of Bafoussam, Cameroun. Follow-ups were scheduled for 1 day, 1 week, 1 month, 3 months, 6 months and 1 year after surgery. But mostly, patients were unable to meet such fixed dates. Instead, if at all, they appeared more or less at random times after surgery. All individual IOP changes at all recording times are shown in figs. 6 and 7. 


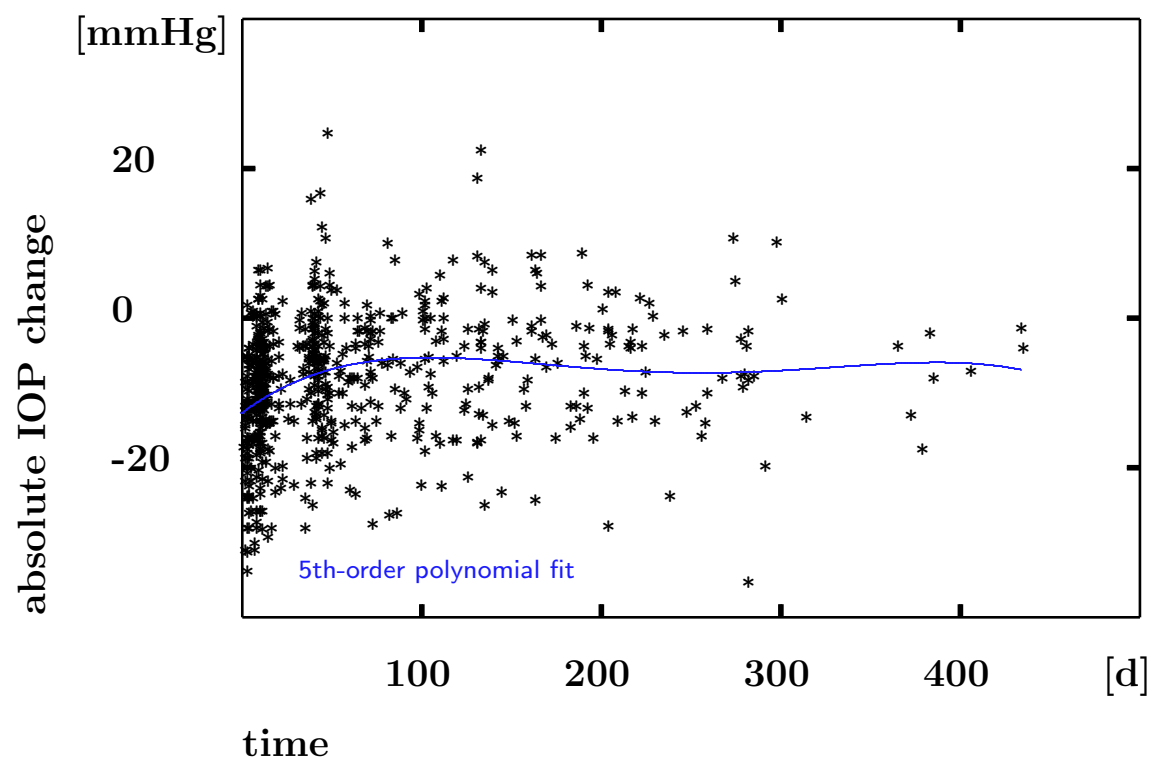

Fig. 6. Absolute Change in IOP The average of the starting IOP was $28.5 \mathrm{mmHg}$.

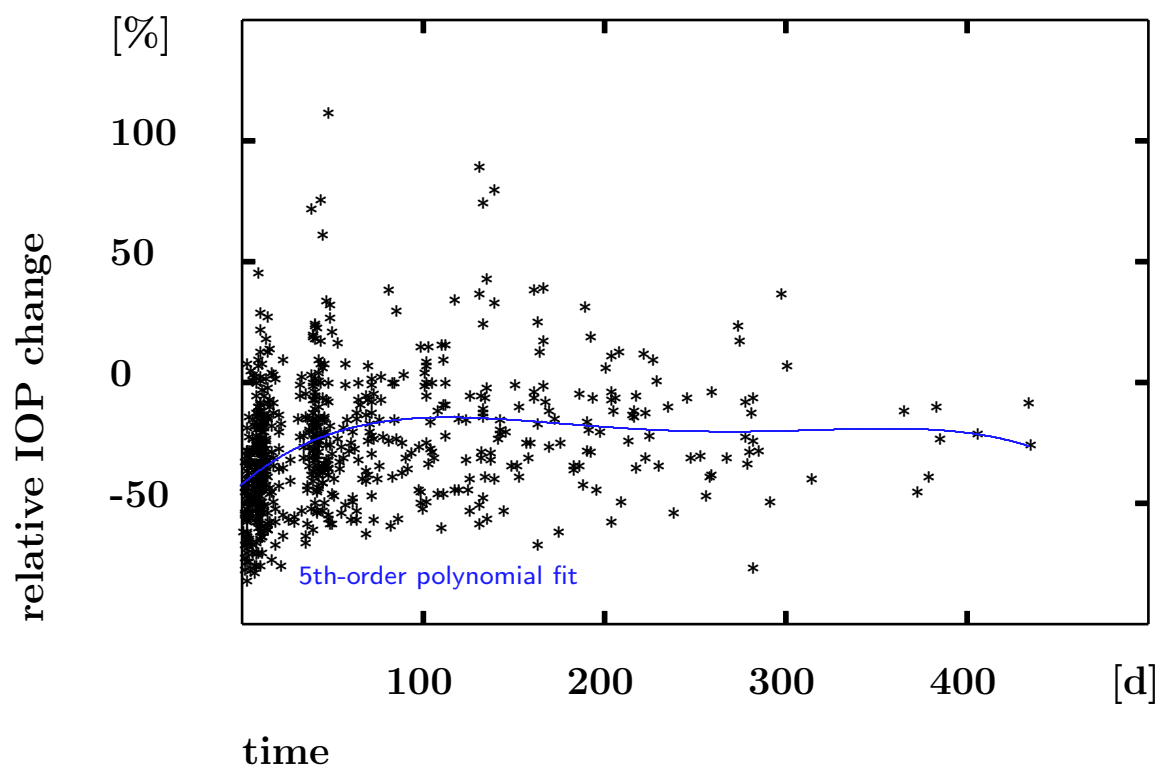

Fig. 7. Relative Change in IOP 


\section{Discussion}

Controlled cyclophotocoagulation with the 810nm laser for Caucasian and with the 940nm laser for African glaucoma eyes is a method with nearly negligible complications. However, the individual IOP reduction is not predictable.

Re-treatments are possible, but an interval of at least 4 weeks is recommended, because a significant prostaglandine release for at least 2 weeks is an unavoidable concomittant of the coagulation (45). The maximum number of re-treatments performed so far was 13 in an eye in which no other glaucoma surgery was possible (only functioning eye of this patient, and this eye had already multiple surgeries). The function of the eye could be preserved at an IOP that finally reached $8 \mathrm{mmHg}$. Even if not explicitely shown for humans, at least a partial recovery must be assumed for the coagulated tissue.

The low complication risk can be understood as a result of the low energy load compared with the uncontrolled coagulation. In Caucasian eyes, the energy per spot is $\approx 1.5 \mathrm{~J}$ and in Africans $\approx 1.0 \mathrm{~J}$, which is to be compared with the much higher values reported from other authors: $3.6 \mathrm{~J}$ (13) or 2.2J to 3.3J (30) in Caucasians and 2.25 to 3.125J in Africans (22). Nd:YAG-laser values are even higher (44).

In Africans, IOP reduction is obviously higher and complication rate lower compared to the uncontrolled coagulation with the 810nm laser (22).

As a consequence of the high power $(5 \mathrm{~W})$ and low exposure time $(\approx 0.2 \mathrm{~s}$ in Africans and $\approx 0.3 \mathrm{~s}$ in Caucasians), the major fraction of energy is thermalized in the highest absorbing tissue, i.e. in the (black) pigmented ciliary epithelium, thus causing a selective coagulation of this target tissue.

As a major drawback, cyclophotocoagulation in general may result in conjunctival scarring which interferes with other procedures such as trabelectomy or shunt tube placement. However, the probability of such conjunctival scarring is reduced by a more selective approach.

To apply such a high power without the risk of very many pop spots, the real time control is an indispensable necessity of the device.

\section{References}

[1] Weekers R, Lavergne G, Watillon M, Gilson M, Legros AM (1961) Effects of photocoagulation of the ciliary body upon ocular tension. Am J Ophthalmol 52:156-163

[2] Beckman H, Kinoshita A, Rota AN, Sugar HS (1972) Transscleral ruby laser irradiation of the ciliary body in the treatment of intractable glaucoma. Trans Am Acad Ophthal Otol 76:423-436

[3] Beckman H, Sugar HS (1973) Neodymium laser cyclophotocoagulation. Arch Ophthalmol 90:27-28

[4] Hampton C, Shields MB, Miller KN, Blasini M (1990) Evaluation of a protocol for transscleral neodymium:YAG cyclophotocoagulation in one hundred patients. Ophthalmology 97:910-917

[5] Brooks AMV, Gillies WE (1991) The use of YAG cyclophotocoagulation to lower pressure in advanced glaucoma. Aust NZ J Ophthal 19:207-210

[6] Heidenkummer HP, Mangouritsas G, Kampik A (1991) Klinische Anwendungen und Ergebnisse der transskleralen Nd:YAG-Zyklophotokoagulation bei therapierefraktärem Glaucom. Klin Mbl Augenheilk 198:174-180

[7] Wright MM, Grajewski AL, Feuer WJ (1991) Nd:YAG cyclophotocoagulation: outcome of treatment for uncontrolled glaucoma. Ophthalmic Surg 22:279-283 
[8] Immonen IJ, Puska P, Raitta C (1994) Transscleral contact krypton laser cyclophotocoagulation for treatment of glaucoma. Ophthalmology 101:876-882

[9] Brancato R, Carassa RG, Bettin P, Fiori M, Trabucchi G (1995) Contact transscleral cyclophotocoagulation with diode laser in refractory glaucoma. Eur J Ophthalmol 5:32-39

[10] Hamard P, Kopel J, Valtot F, Quesnot S, Hamard H, Haut J (1995) Traitement des glaucomes réfractaires par cyclophotocoagulation au laser à diode. J Fr Ophthalmol 18:447-454

[11] Hawkins TA, Stewart WC (1993) One-year results of semiconductor transscleral cyclophotocoagulation in patients with glaucoma. Arch Ophthalmol 111:488-491

[12] Hennis HL, Stewart WC (1992) Semiconductor diode laser transscleral cyclophotocoagulation in patients with glaucoma. Am J Ophthalmol 113:81-85

[13] Omofolasade K, Gaasterland DE, Pollack IP, Enger CL (1996) Long-term outcome of initial ciliary ablation with contact diode laser transscleral cyclophotocoagulation for severe glaucoma. Ophthalmology 103:1294-1302

[14] Maus M, Katz LJ (1990) Choroidal detachment, flat anterior chamber, and hypotony as complications of neodymium:YAG laser cyclophotocoagulation. Ophthalmology 97:69-72

[15] Smith RS, Stein MN (1969) Ocular hazards of transscleral laser radiation: II. Intraocular injury produced by ruby and neodymium lasers. Am J Ophthalmol 67:100-110

[16] Hamada M, Suzuki R, Kurimoto S (1991) Transient complete visual loss during transscleral cyclophotocoagulation. Jap J Clin Ophthalmol 45:949-951

[17] Edwards DP, Brown SV, Higginbotham E (1989) Sympathetic ophthalmia following Nd:YAG cycloptherapy. Ophthalmic Surg 20:544-546

[18] Bechrakis NE, Müller-Stolzenburg NW, Helbig H (1994) Sympathetic ophthalmia following laser cyclocoagulation. Arch Ophthalmol 112:80-84

[19] Geyer O, Neudorfer M, Lazar M (1993) Retinal detachment as a complication of neodymium:yttrium:aluminium garnet laser cyclocoagulation. Ann Ophthalmol 25:170-172

[20] Johnson SM (1998) Neurotrophic corneal defects after diode laser cycloablation. Am J Ophthalmol 126:725-727

[21] Sabry K, Vernon SA (1999) Scleral perforation following trans-scleral cyclodiode. Br J Ophthalmol 83:502-503

[22] Egbert PR, Fiadoyor S, Budenz DL, Dadzie P, Byrd S (2001) Diode laser transscleral cyclophotocoagulation as a primary surgical treatment for primary open-angle glaucoma. Arch Ophthalmol 119:345-350

[23] Kramp K, Vick HP, Guthoff R (2002) Transscleral diode laser contact cyclophotocoagulation in the treatment of different glaucomas, also as primary surgery. Graefes Arch Clin Exp Ophthalmol 240:698-703

[24] Federman JL, Ando F, Schubert HD, Eagle RC (1987) Contact laser for transscleral photocoagulation. Ophthalmic Surg 18:183-184

[25] Allingham RR, Kater AW de, Bellows AR, Hsu J (1990) Probe placement and power levels in contact transscleral neodymium:YAG cyclophotocoagulation. Arch Ophthalmol 108:738-742

[26] England C, Van der Zypen E, Fankhauser F, Kwasniewska S (1988) A comparison of optical methods used for transscleral cyclophotocoagulation in rabbit eyes produced with the Nd:YAG laser: a morphological physical and clinical analysis. Lasers Light Ophthalmol 2:87-102 
[27] Kwasniewska S, Fankhauser F, Van der Zypen E, Rol P, Henchoz PD, England C (1988) Acute effects following transscleral contact irradiation of the ciliary body and the retina/choroid with the cw Nd:YAG laser. Lasers Light Ophthalmol 2:25-34

[28] Schuman JS, Noecker RJ, Puliafito CA, Jacobsson JJ, Shepps GJ, Wang N (1991) Energy levels and probe placement in contact transscleral semiconductor diode laser cyclophotocoagulation in human cadaver eyes. Arch Ophthalmol 109:1534-1538

[29] Takahashi H, Okisaka S (1991) Safety and effectiveness of contact transscleral cyclophotocoagulation with continuous-wave Nd:YAG laser. Jap J Clin Ophthalmol 45:1233-1237

[30] Roider J, Schmidt-Erfurth U, El-Hifnawi E, Herboth T, Hoerauf H, Birngruber R, Laqua H (1996) Zyklophotokoagulation mit dem Diodenlaser im Kontaktverfahren mit einer neuen fokussierenden Sonde. Ophthalmologe 93:576-580

[31] Preußner PR, Schwenn O (1995) Steps to optimize transscleral photocoagulation. Graefes Arch Clin Exp Ophthalmol 233:302-306

[32] Echelman DA, Stern RA, Shields SR, Simmons RB, Shields MB (1995) Variability of contact transscleral neodymium:YAG cyclophotocoagulation. Invest Ophthalmol Vis Sci 36:497-502

[33] Preußner PR, Boos N, Faßbender K, Schwenn O, Pfeiffer N (1997) Real-time control for transscleral cyclophotocoagulation. Graefes Arch Clin Exp Ophthalmol 235:794-801

[34] Preußner PR (1998) Kontrollierte Zyklophotokoagulation. Ophthalmologe 95:645-650

[35] Francis A. L'Esperance, Ophthalmic lasers, 3rd ed., Mosby, 1989.

[36] Geeraets WJ, Williams RC, Chan G, Ham WT, Guerry D, Schmidt FH (1960) The loss of light energy in retina and choroid. Arch Ophthalmol 64: 606-615

[37] Raivio VE, Immonen IJ, Puska PM (2001) Transscleral contact krypton laser cyclophotocoagulation for treatment of posttraumatic glaucoma. J Glaucoma 10:77-84

[38] Raivio VE, Vesaluoma MH, Tervo TM, Immonen IJ, Puska PM (2002) Corneal innervation, corneal mechanical sensitivity, and tear fluid secretion after transscleral contact 670nm diode laser cyclophotocoagulation. J Glaucoma 11:446-453

[39] Liu GJ,Mizukawa A, Okisaka S (1994) Mechanism of intraocular pressure decrease after contact transscleral continuous-wave Nd:YAG laser cyclophotocoagulation. Ophthalmic Res 26:65-79

[40] Schröder G (1990) Technische Optik. Kamprath-Reihe, Vogel, Würzburg, ISBN 3-8023-0067-X

[41] Rol P, Niederer P, Dürr U, Henchoz PD, Fankhauser F (1990) Experimental investigations on the light scattering properties of the human sclera. Laser and Light in Ophthalmol 3:201-212

[42] Vogel A, Dlugos C, Nuffer R, Birngruber R (1991) Die optischen Eigenschaften der menschlichen Sklera und deren Bedeutung für transsklerale Laseranwendungen. Fortschr Ophthalmol 88:754-761

[43] Holbach M, Fiadoyor S, Preußner PR. Controlled cyclophotocoagulation for the therapy of primary open angle glaucoma in African eyes. Presentation on the 101. congress of the Deutsche Ophthalmologische Gesellschaft (DOG), Berlin, 25.-28.09.2003

[44] Krott R, Diestelhorst M, Zollweg M, Krieglstein GK (1997) Zur Dosis-Wirkungs-Beziehung der transskleralen Kontaktzyklophotokoagulation. Ophthalmologe 94:273-276

[45] Nasisse MP, McGahan MC, Shields MB, Echelman D, Fleisher LN (1992) Inflammatory effects of continuous-wave neodymium:yttrium aluminum garnet laser cyclophotocoagulation. Invest Ophthalmol Vis Sci 33:2216-2223 


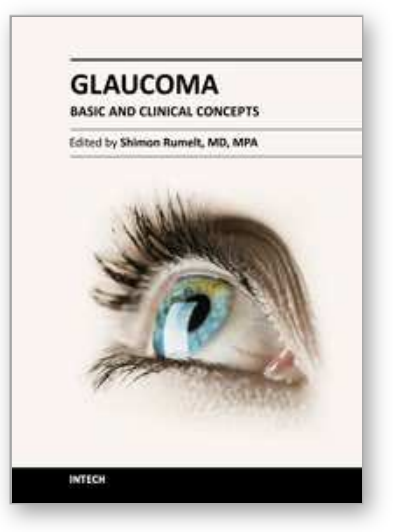

\author{
Glaucoma - Basic and Clinical Concepts \\ Edited by Dr Shimon Rumelt
}

ISBN 978-953-307-591-4

Hard cover, 590 pages

Publisher InTech

Published online 11, November, 2011

Published in print edition November, 2011

This book addresses the basic and clinical science of glaucomas, a group of diseases that affect the optic nerve and visual fields and is usually accompanied by increased intraocular pressure. The book incorporates the latest development as well as future perspectives in glaucoma, since it has expedited publication. It is aimed for specialists in glaucoma, researchers, general ophthalmologists and trainees to increase knowledge and encourage further progress in understanding and managing these complicated diseases.

\title{
How to reference
}

In order to correctly reference this scholarly work, feel free to copy and paste the following:

Paul-Rolf Preußner (2011). Controlled Cyclophotocoagulation, Glaucoma - Basic and Clinical Concepts, Dr Shimon Rumelt (Ed.), ISBN: 978-953-307-591-4, InTech, Available from:

http://www.intechopen.com/books/glaucoma-basic-and-clinical-concepts/controlled-cyclophotocoagulation

\section{INTECH}

open science | open minds

\author{
InTech Europe \\ University Campus STeP Ri \\ Slavka Krautzeka 83/A \\ 51000 Rijeka, Croatia \\ Phone: +385 (51) 770447 \\ Fax: +385 (51) 686166 \\ www.intechopen.com
}

\author{
InTech China \\ Unit 405, Office Block, Hotel Equatorial Shanghai \\ No.65, Yan An Road (West), Shanghai, 200040, China \\ 中国上海市延安西路65号上海国际贵都大饭店办公楼 405 单元 \\ Phone: +86-21-62489820 \\ Fax: +86-21-62489821
}


(C) 2011 The Author(s). Licensee IntechOpen. This is an open access article distributed under the terms of the Creative Commons Attribution 3.0 License, which permits unrestricted use, distribution, and reproduction in any medium, provided the original work is properly cited. 